\author{
РОЗВИТОК \\ ІННОВАЦІЙНОї \\ ДІЯЛЬНОСТІ НА \\ ПЕРЕРОБНИХ \\ ПІДПРИЕМСТВАХ АПК ${ }^{14}$
}

\author{
ГОНТАРУК Я.В. \\ асистент кафедри аграрного менеджмменту, \\ Вінницький національний \\ аграрний університет \\ (м. Вінниця)
}

У статті розглянуто сучасний стан впровадження інновачій у переробній промисловості АПК. Проаналізовано показники інноваційного розвитку економіки та визначено основні функиіі центрів стимулювання інновачій. Досліджено основні проблеми розвитку інновачій на підприємствах переробних галузей агропромислового комплексу. Визначено обсяги споживання газойлів за регіонами держави. Досліджено стратегічні напрямки розвитку інновацій у харчовій промисловості. Запропоновано заходи з адаптаціі переробних підприємств в умовах інтеграції у світовий економічний простір. Визначено механізми комплексної реструктуризації підприємств галузі на інвестиційно-інноваційній основі. Розроблено модель розвитку інноваційної діяльності на переробних підприємствах аграрної сфери. Обтрунтовано необхідність страхування фінансових ризиків при проведенні реструктуризаиії підприємств переробної сфери аграрного сектору.

Визначено перспективні напрямки розвитку переробної галузі АПК на інвестиційноінновачійній основі. До формування стійких конкурентних переваг підприємств ичих галузей потрібно підходити з погляду системного підходу та проводити комплекс заходів спрямований на: реструктуризацію малоефективних підприємств галузі, комплексну державну підтримку сільського господарства, переорієнтаџію з виробництва сировини на виробництво готової продукиії, диверсифікаиію виробниитва, залучення достатнього обсягу інвестииій для розвитку переробних галузей АПК. Цей комплекс заходів дозволить оздоровити підприємства переробної промисловості та адаптувати їх до вимог глобалізованих ринків агропродовольства.

Розробка відповідного організаційно-економічного механізму зі створення інноваційного виду підприємницької діяльності, який дасть змогу подолати вище викладені перешкоди для розвитку изього виду діяльності, має включати такі 3 етапи: поглиблених досліджень у сфері створення закритого ииклу з переробки олійних культур, в тому числі на базі ННВК «Всеукраїнський науково-навчальний консориіум»; економічного обтрунтування на основі проведених експериментальних досліджень, дочільності створення переробних кооперативів із виробництва біодизеля; створення проєктно-кошторисної документації з організаиії переробки олійної продукиії та реструктуризації спиртових заводів на інновачійній основі: розробки державної програми розвитку обслуговувальних кооперативів із передбаченням державного дотування переробної галузі АПК.

Ключові слова: інтеграція, реструктуризація, інновації, інвестиції, рентабельність, оновлення, стратегія, ефективність.

Табл.: 7. Рис.: 2. Літ.: 10.

${ }^{14}$ ГОНТАРУК Я.В., 2020 


\title{
DEVELOPMENT OF INNOVATIVE ACTIVITY AT PROCESSING ENTERPRISES OF AGRO-INDUSTRIAL COMPLEX
}

\author{
HONTARUK Yaroslav, \\ Lecturer of the Department of Agrarian \\ Management, \\ Vinnytsia National Agrarian University \\ (Vinnytsia)
}

The article deals with the current state of innovations in agro-processing industry. Indicators of innovative development of the economy are analyzed and the main functions of centers of innovation stimulation are determined. The basic problems of development of innovations at the enterprises of processing industries of the agro-industrial complex are investigated. Determination of gas oil consumption by regions of the state. Strategic directions of development of innovations in the food industry are investigated. Measures on adaptation of processing enterprises in terms of integration into the world economic space are proposed. The mechanisms of complex restructuring of the enterprises of the branch on the basis of investment and innovation basis are defined. The model of development of innovative activity at processing enterprises of agrarian sphere is developed. The necessity of insurance of financial risks at carrying out restructuring of enterprises of processing sector of agrarian sector is substantiated. Prospective directions of development of agro-processing industry on the basis of investment and innovation basis are determined.

In order to create sustainable competitive advantages of the enterprises of these industries, it is necessary to approach from the point of view of a systematic approach and to carry out a set of measures aimed at: restructuring of inefficient enterprises of the industry, comprehensive state support of agriculture, reorientation from production of raw materials to production of finished products, diversification of production, attracting sufficient volume development of agricultural processing industries. This set of measures will allow to improve the enterprises of processing industry and adapt them to the requirements of globalized markets of agro-food.

The development of an appropriate organizational and economic mechanism for the creation of an innovative type of entrepreneurial activity, which will help to overcome the above obstacles to the development of this type of activity, should include the following stages: in-depth studies in the field of closed cycle for the processing of oilseeds, including on the basis of NNC "All-Ukrainian Scientific and Educational Consortium»; economic justification, on the basis of experimental studies, the feasibility of creating processing cooperatives for biodiesel production; creation of projectdesign documentation on organization of oil production processing and restructuring of alcohol factories on an innovative basis: development of the state program of development of servicing cooperatives with anticipation of the state subsidy of agro-processing industry. efficiency.

Keywords: integration, restructuring, innovation, investment, profitability, renewal, strategy,

Tabl.: 7. Fig.: 2. Lit.: 10.

\section{РАЗВИТИЕ ИННОВАЦИОННОЙ ДЕЯТЕЛЬНОСТИ НА ПЕРЕРАБАТЫВАЮЩИХ ПРЕДПРИЯТИЯХ АГРОПРОМЫШЛЕННОГО КОМПЛЕКСА}

Гонтарук Я. В., ассистент кафедры аграрного менеджмента, Винницкий национальный аграрный университет 
В статье рассмотрено современное состояние внедрения инноваций в перерабатывающей промышленности АПК. Проанализированы показатели инновационного развития экономики и определении основные функции центров стимулирования инноваций. Исследованы основные проблемы развития инноващий на предприятиях перерабатывающих отраслей агропромышленного комплекса. Определении объемы потребления газойлей по регионам страны. Исследовано стратегические направления развития инноваций в пищевой промышленности. Предложены меры по адаптаџии перерабатывающих предприятий в условиях интеграции в мировое экономическое пространство. Определень механизмь комплексной реструктуризаџии предприятий отрасли на инвестиционно-инновационной основе. Разработана модель развития инновачионной деятельности на перерабатьвающих предприятиях аграрной сферы. Обоснована необходимость страхования финансовых рисков при проведении реструктуризации предприятий перерабатывающей сферы аграрного сектора.

Определены перспективные направления развития перерабатывающей отрасли АПК на инвестииионно-инновачионной основе.

Для формирования устойчивых конкурентных преимуществ предприятий данных отраслей нужно подходить с точки зрения системного подхода и проводить комплекс

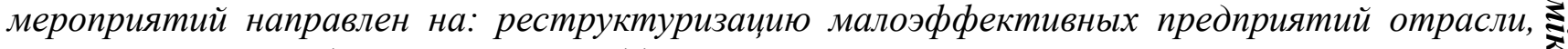
комплексную государственную поддержку сельского хозяйства, переориентацию $c$ s производства сырья на производство готовой продукиии, диверсификации производства, : привлечения достаточного объема инвестиций для развития перерабатывающих отраслей АПК. Данный комплекс мер позволит оздоровить предприятия перерабатьвающей промымленности $u$ адаптировать $и x{ }_{\kappa}$ требованиям глобализованных рынков агропродовольства.

Разработка соответствующего организациионно-экономического механизма по созданию инноваџионного вида предпринимательской деятельности требует, который позволит преодолеть выше изложении препятствия для развития данного вида деятельности должен включать следующие из этапа: углубленных исследований в области создания закрытого ииила по переработке масличных культур в том числе на базе ННПК «Всеукраинский научно-учебный консорииум»; экономического обоснования, на основе проведенных экспериментальных исследований, иелесообразности создания перерабатываюших кооперативов по производству биодизеля; создание проектно-сметной документащии по организащии переработки масличной продукции и реструктуризаџии спиртовых заводов на инновационной основе: разработки государственной программы развития обслуживающих кооперативов с предвидением государственного дотирования перерабатывающей отрасли АПК.

Ключевые слова: интеграция, реструктуризация, инновации, инвестиции, рентабельность, обновления, стратегия, эффективность.

Табл.: 7. Рис.: 2. Лит.: 10.

Постановка проблеми. У сучасних умовах господарювання інноваційний розвиток переробних підприємств АПК є одним із пріоритетних для економіки. За умов світового зростання цін на продовольство, швидких процесів інтеграції та глобалізації визначення перспектив інноваційного розвитку переробних галузей АПК є однією з головних проблем розробки довгострокової стратегії: розвитку економіки країни. Значний вплив на інноваційну діяльність суб'єктів ঞ господарювання здійснюють такі чинники зовнішнього середовища, як чинні норми законодавства, податкова і кредитна політика держави, які, внаслідок своєї недосконалості, ускладнюють проведення процедур із реструктуризації 
підприємств на інноваційно-інвестиційній основі та їхньої інтеграції у світовий економічний простір, а також слабкий розвиток академічного підприємництва в аграрних вишах.

Одним із основних завдань у виборі інноваційної стратегії розвитку переробних підприємств має стати низка стратегічних заходів, комплексна реалізація яких повною мірою дозволить створити сприятливі умови для підвищення конкурентоспроможності підприємств.

При виборі стратегії інноваційного розвитку підприємств переробної промисловості вирішальну роль відіграють стан підприємств галузі та місце в ній певного підприємства. Підприємства-лідери в сучасних ринкових умовах змушені максимально використовувати свої можливості для зміцнення позиції в галузі на інвестиційно-інноваційній основі.

Аналіз останніх досліджень і публікацій. Дослідження проблематики інноваційного розвитку переробних підприємств АПК висвітлено у працях - вітчизняних вчених: Савицького Е.Е. [1], Калетніка Г.М., Гончарук Т.В. [2], Гончарук I.В. [3], Губіної В.В. [5] та зарубіжних Т. Бренера [6] Дж. Хіменса [7] та ін. Проте, недостатньо досліджено практичні аспекти інноваційноінвестиційного стратегічного розвитку переробної промисловості АПК.

Савицький Е.Е. чітко охарактеризував теоретичні аспекти інноваційного розвитку в АПК та систематизував підходи до трактування «інновацій в АПК» [1]. Калетніком Г.М., Гончарук І.В. та Гончарук Т.В. проведені грунтовні дослідження світового та вітчизняного досвіду у сфері інноваційного забезпечення розвитку біопаливної галузі [2-3]. У попередніх дослідженнях визначено перспективи розвитку академічного підприємництва в аграрних вишах [4]. Інновації як фактор конкурентоспроможності в харчовій промисловості проаналізовані Губіним В.В. [5]. Непараметричний підхід до інноваційних прогалин та економічного зростання у світовій економіці досліджено в працях Т. Бренера [6] та Дж. Хіменса [7]. Теоретичні підходи до інноваційної реструктуризації промислового комплексу України розкритті Гусєвим В.О. [10].

Мета статті. Провести аналіз інноваційного розвитку підприємств переробної промисловості в умовах глобалізації соціально-економічних процесів на інвестиційно-інноваційній основі. Визначення перспектив розвитку інновацій на переробних підприємствах АПК в середньо та довгостроковому періоді. Дослідження напрямів комплексної реструктуризації підприємств переробної галузі з урахуванням сучасних реалій розвитку економіки держави.

Виклад основного матеріалу. Розвиток інноваційної діяльності на переробних підприємствах АПК має бути сконцентрований на освоєнні передових технологій виробництва, що дасть можливість вивести галузь на світові ринки та досягти зростання ВВП держави. Особливу увагу варто приділити опануванню на підприємствах переробної промисловості АПК технологій виробництва біопалива.

Дослідження трактування сутності інновацій в АПК розкритті 
Савицьким Е.Е. (табл. 1).

Таблиия 1

Розкриття сутності поняття «інновації в АПК» у роботах вітчизняних і зарубіжних науковців

\begin{tabular}{|c|c|c|}
\hline № ח/П & Автор & Визначення \\
\hline 1 & Бухвостов Ю. В. & $\begin{array}{l}\text { Результат праці, одержаний завдяки застосуванню нових наукових знань, щс } \\
\text { перетворюють процес функціонування та розвитку виробничо-господарсько } \\
\text { системи АПК у напрямі підвищення її ефективності, стійкості й системної якост } \\
\text { відносин }\end{array}$ \\
\hline 2 & Іванов В. А. & $\begin{array}{l}\text { Реалізація в господарській практиці результатів досліджень і розробок у вигляд } \\
\text { нових сортів рослин, порід та видів тварин і кросів птиці, нових та поліпшених } \\
\text { продуктів харчування, матеріалів, нової техніки, нових технологій в рослинництві } \\
\text { тваринництві й переробній промисловості, нових форм організації та управління } \\
\text { різноманітними сферами економіки, нових підходів до соціальних послуг, як } \\
\text { уможливлюють підвищити ефективність виробництва }\end{array}$ \\
\hline 3 & Кот О.В. & $\begin{array}{l}\text { Системні запровадження в аграрну сферу результатів науково-дослідницької роботи } \\
\text { що приводять до позитивних якісних і кількісних змін у характеристиц } \\
\text { взаємозв'язків між біосферою та техносферою, а також поліпшують стан } \\
\text { навколишнього середовища }\end{array}$ \\
\hline 4 & Попова О.В. & $\begin{array}{l}\text { Інновація, яка зачіпає безпосередньо (або опосередковано, в межах технологічного } \\
\text { ланцюга) процеси, учасниками яких є людина, машина (обладнання, інструмент } \\
\text { тощо) й компонент навколишнього середовища (тварина, рослина тощо), існування } \\
\text { яких у природному середовищі (без участі людини) неможливе або можливе із } \\
\text { втратою базових функціональних характеристик }\end{array}$ \\
\hline 5 & Шайтан Б. І. & $\begin{array}{l}\text { Нові технології, нова техніка, нові сорти рослин, нові породи тварин, нові добрива } \\
\text { та засоби захисту рослин і тварин, нові методи профілактики й лікування тварин } \\
\text { нові форми організації, фінансування та кредитування виробництва, нові підходи дс } \\
\text { підготовки, перепідготовки й підвищення кваліфікації кадрів і т.д. }\end{array}$ \\
\hline 6 & Янковська О.I. & $\begin{array}{l}\text { Кінцевий результат впровадження новації у галузі сільського господарства (сорту } \\
\text { рослин, порід тварин, засобів захисту рослин або тварин, технологій вирощуванн } \\
\text { тощо), який привів до одержання економічного, соціального, екологічного та інших } \\
\text { видів ефекту }\end{array}$ \\
\hline
\end{tabular}

Проте, доцільно розглядати інноваційну діяльність в АПК як процес взаємодії аграрної науки та підприємств переробних галузей із метою освоєння нових технологій виробництва, управління підприємствами та розробкою нової продукції. Особливо актуальним це є у сфері розвитку біопалива, особливо у галузі альтернативної енергетики.

Фундамент інноваційного прориву формують енергоощадні технології і пов'язана з ними біоенергетика, які є запорукою зменшення залежності людства від викопних джерел енергії. Під впливом зазначених процесів відбуваються суттєві трансформації світової агросфери, які, відповідно, несуть зміни у вітчизняний агропродовольчий розвиток [2, с.157].

Підприємницька діяльність зазначеного напряму $\epsilon$ інноваційною системою, адже розвиток біопаливної галузі нашої країни надає можливості широкої перспективи та системного упровадження нововведень, які в майбутньому здатні покращити структуру енергетичного балансу країни.

Однією 3 таких особливостей $\epsilon$ наявність достатніх можливостей нарощування виробництва тих видів сільськогосподарської продукції, яка 
потенційно може бути використана для виробництва біопалива - це зернові та зернобобові, технічні культури, особливо кукурудза та соя, а також цукрові буряки [3, с.157].

Для впровадження в життя інновацій доцільно також максимізувати продукування інновацій науково-дослідними установами, налагодити взаємозв'язок між наукою та виробництвом, розвивати академічне підприємництво в аграрних вишах.

Розвиток академічного підприємництва в аграрних вишах доцільно сьогодні провадити в таких напрямках:

- вирощування нових сортів зернових та технічних культур, адаптованих до українських природно-кліматичних умов відповідно до потреб спиртової промисловості;

- виведення нових порід тварин молочного напрямку;

- створення засобів механізації сільськогосподарського виробництва

- насамперед для особистих селянських господарств пристосованих до обробітку порівняно невеликих посівних площ та невисокої вартості; продукції;

створення технологічних ліній для переробки сільськогосподарської

розробка організаційно-економічних механізмів створення підприємств закритого циклу переробки продукції сільського господарства на малих переробних підприємствах;

- створення техніко-економічних проєктів із обгрунтування перспектив виробничої реструктуризації спиртових заводів із переходом їх на енергоощадні технології (створення проєктів із переформатування заводів на виробництво біоетанолу та виробництво з побічної продукції біогазу) [4].

Селекція нових сортів рослин та виведення нових порід тварин дасть можливість зменшити витрати підприємств на дорогий посадковий матеріал, що сьогодні імпортується та дасть поштовх до розвитку галузі тваринництва та м'ясо-молочної промисловості.

На думку Губіної В.В., із метою інтеграції інновацій різного виду i прискорення їх використання в організаціях регіону доцільне створення центрів, які б займалися проблемами взаємодії наукових, освітніх та виробничих структур, надавали консультаційну та інформаційну підтримку інноваційному бізнесу, брали участь у розробці методів стимулювання інноваційної діяльності, здійснювали пошук джерел фінансування інноваційних проєктів, а також здійснювали контроль за витрачанням залучених коштів.

Головна мета їхнього функціонування - створення умов для активізації інноваційної діяльності в харчовій промисловості в усьому ланцюжку створення вартості. Організаційна форма - саморегульована організація, що об'єднує представників бізнес-спільноти, регіональних і муніципальних органів влади, громадських професійних організацій, потенційних інвесторів і мешканців регіону, в якому створюється центр стимулювання інновацій в харчовій промисловості. 

функціі:

Центри стимулювання інновацій повинні здійснювати такі основні

- створення умов для взаємодії організацій і підприємств, які виробляють і реалізують продукти харчування (представників сільського господарства, харчової промисловості, харчового машинобудування, торгівлі);

- пошук джерел фінансування інноваційних проєктів у харчовій промисловості;

- контроль витрачання залучених ресурсів і якості інноваційної продукції [5].

Обираючи шлях до інтеграції в Європейський Союз, для українського суспільства актуальним $\epsilon$ дослідження не лише його 92 стратегічних ініціатив як перспектив забезпечення розвитку економіки України, а й досвіду окремих країн. Адже кожен із членів Свросоюзу має власну історію забезпечення інноваційного розвитку, тобто різні вихідні позиції (умови), різноманітні програми та інструменти стимулювання i, як наслідок, різні результати. Аналіз національних програм забезпечення інноваційного розвитку в окремих країнах Євросоюзу показав, що здебільшого такі програми спрямовані на сприяння створенню науково-дослідних та інноваційних проєктів в окремих галузях економіки 3 : можливістю використання державних інструментів фінансової підтримки [6-7].

Нині частка інноваційно-активних промислових підприємств не досягає навіть 20 відсотків від загальної кількості, обсяг витрат на інноваційну діяльність порівняно з 2016 роком значно скоротився через негативні соціально-економічні процеси в державі. Незначна частина від інноваційних витрат спрямована на науково-дослідні роботи.

У той же час більшість іде на закупівлю обладнання, яке є здебільшого імпортним, хоча в державі є значний науковий потенціал, залучивши який можна зменшити імпорт та забезпечити розвиток наукових розробок та їх впровадження у промислове виробництво (табл. 2).

При розробці відповідних механізмів взаємодії між науковими установами та виробничими підприємствами можливо забезпечити не тільки зростання наукових показників розвитку, а й забезпечити вітчизняну промисловість замовленнями у сфері важкого машинобудування та зменшення валового імпорту в Україні з подальшим зниженням вартості реалізації інноваційних проєктів.

Коливання валютних котирувань та високі відсоткові ставки по кредитах не дають змоги повною мірою реалізувати інноваційні проєкти і частка інноваційно активних промислових підприємств $\epsilon$ незначною, а обсяг реалізації інноваційної продукції має тенденцію до спаду й у 2018 році лише $1 \%$ всієї продукції промислових підприємств реалізувалася як інноваційна при: ڤ્ง одночасному зростанні кількості товарів інновацій, які $\epsilon$ новими для ঞ підприємства чи для ринку більш ніж на третину, порівняно з 2013 роком (табл. $3)$. 
EФМ

http://efm.vsau.org/

Таблиия 2

Загальний обсяг витрат за напрямами інноваційної діяльності промислових підприємств

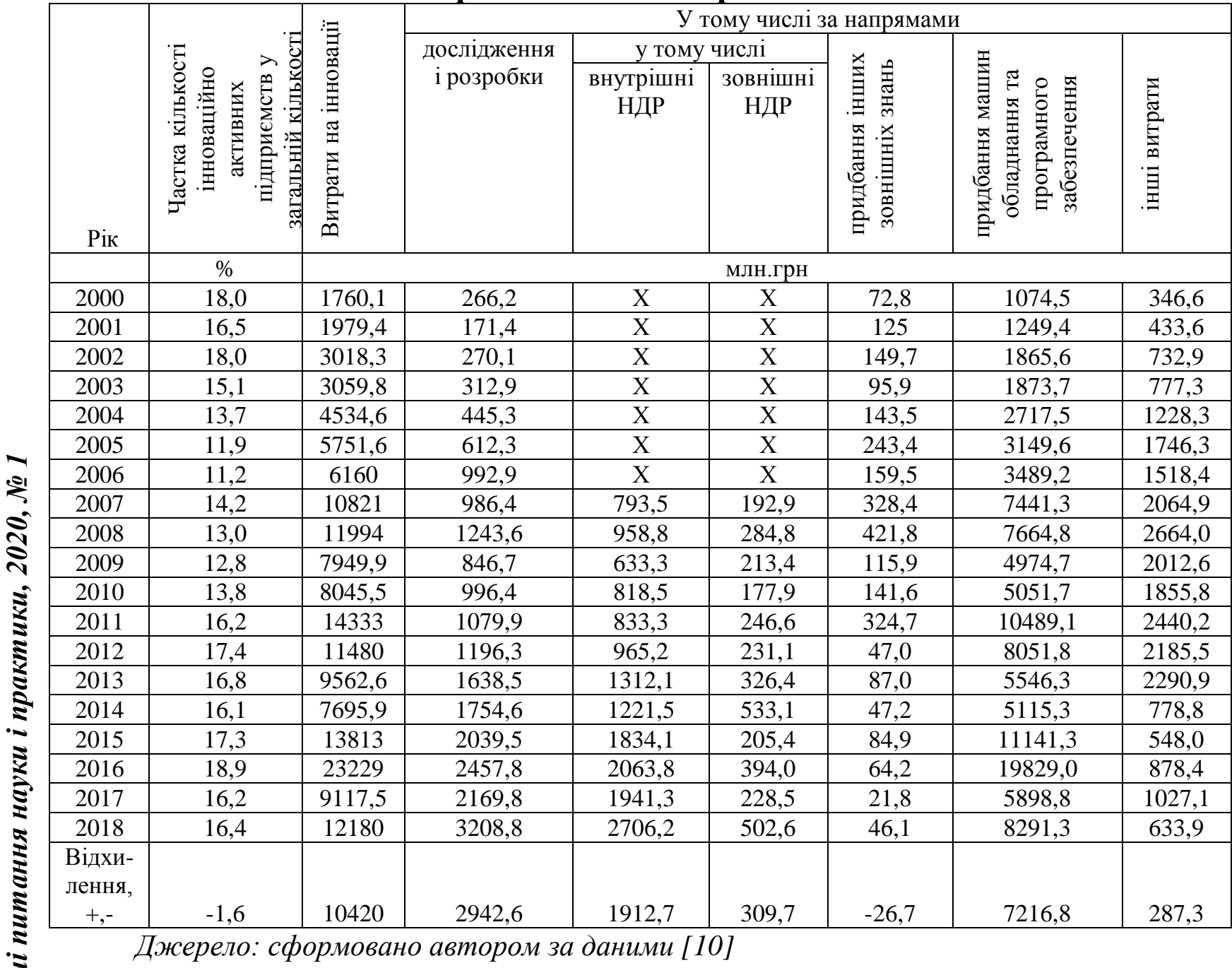

Серед 739 підприємств, що впроваджували інновації у 2018 році в Україні лише 177 належать до переробної промисловості АПК і тільки третина від цієї кількості впроваджувала інновації, які $є$ новими для ринку. У масштабах країни 46 інноваційно активних підприємств переробних підприємств $є$ мізерною (табл. $4)$.

Зростали саме показники впровадження нових технологічних процесів, що знову зумовлювало імпорт технологій.

Розвиток інновацій у переробній промисловості має опиратися, насамперед, на виробництво альтернативних видів палива, а саме біодизеля та біоетанолу.

Загалом більше половини споживання газойлів у 2018 році (63\% від загальних обсягів) припадало на підприємства та організації 11 регіонів країни. Із них частка Дніпропетровської області становила 9,6\%, Полтавської - 6,9\%, Одеської - 6,6\%, м. Києва - 6,4\%, Львівської - 6,2\%, Київської, - 5,6\%, 
Харківської - 5,4\%, Вінницької - 4,3\%, Запорізької - 4,0\%, Донецької та Миколаївської - по 3,8\%.

Табличя 3

Основні показники інноваційної діяльності промислових підприсмств

\begin{tabular}{|c|c|c|c|c|c|c|c|}
\hline Показник & 2013 p. & 2014 p. & $2015 \mathrm{p}$ & $2016 \mathrm{p}$. & $2017 \mathrm{p}$. & 2018 p. & $\begin{array}{c}\text { Відхилення } \\
,+,- \\
\end{array}$ \\
\hline $\begin{array}{l}\text { Кількість інноваційно активних } \\
\text { промислових підприємств, од }\end{array}$ & 1715 & 1609 & 824 & 834 & 759 & 777 & -938 \\
\hline $\begin{array}{l}\text { \% до загальної кількості } \\
\text { промислових підприємств }\end{array}$ & 16,8 & 16,1 & 17,3 & 18,9 & 16,2 & 16,4 & $-0,4$ \\
\hline Витрати на інновації, млн. грн & 9562 & 7695 & 13813 & 23229 & 9117 & 12180 & 2618 \\
\hline $\begin{array}{l}\text { \% до загального обсягу } \\
\text { реалізованої промислової продукції } \\
\text { (товарів, послуг) }\end{array}$ & 0,9 & 0,8 & 0,8 & 0,7 & 0,4 & 0,4 & $-0,5$ \\
\hline $\begin{array}{l}\text { \% до загального обсягу } \\
\text { реалізованої інноваційної продукції } \\
\text { (товарів, послуг) }\end{array}$ & 26,6 & 30 & 59,9 & $\ldots$ & 51,5 & 49 & 22,4 \\
\hline $\begin{array}{l}\text { Кількість промислових } \\
\text { підприємств, що впроваджували } \\
\text { інновації (продукцію та/або } \\
\text { технологічні процеси), од }\end{array}$ & 1312 & 1208 & 723 & 735 & 672 & 739 & -573 \\
\hline $\begin{array}{l}\text { \% до загальної кількості } \\
\text { промислових підприємств }\end{array}$ & 12,9 & 12,1 & 15,2 & 16,6 & 14,3 & 15,6 & 2,7 \\
\hline $\begin{array}{l}\text { Кількість упроваджених у } \\
\text { виробництво нових технологічних } \\
\text { процесів, од }\end{array}$ & 1576 & 1743 & 1217 & 3489 & 1831 & 2002 & 426 \\
\hline $\begin{array}{l}3 \text { них нових або суттєво } \\
\text { поліпшених маловідходних, } \\
\text { ресурсозберігаючих }\end{array}$ & 502 & 447 & 458 & 748 & 611 & 926 & 424 \\
\hline $\begin{array}{l}\text { Кількість упроваджених видів } \\
\text { інноваційної продукції (товарів, } \\
\text { послуг), од }\end{array}$ & 3138 & 3661 & 3136 & 4139 & 2387 & 3843 & 705 \\
\hline $\begin{array}{l}3 \text { них нових видів машин, } \\
\text { устаткування, приладів, апаратів }\end{array}$ & 809 & 1314 & 966 & 1305 & 751 & 920 & 111 \\
\hline $\begin{array}{l}\text { Обсяг реалізованої інноваційної } \\
\text { продукції (товарів, послуг), } \\
\text { млн.грн }\end{array}$ & 35891 & 25669 & 23050 & $\ldots$ & 17714 & 24861 & -11031 \\
\hline $\begin{array}{l}\text { \% до загального обсягу } \\
\text { реалізованої промислової продукції } \\
\text { (товарів, послуг) }\end{array}$ & 3,3 & 2,5 & 1,4 & $\ldots$ & 0,7 & 0,8 & $-2,5$ \\
\hline
\end{tabular}

Джерело: сформовано автором за даними [10]

Найвагоміше збільшення обсягів використання газойлів відбулося в м. Києві (на 17,9\%), Чернігівській (на 14,5\%), Полтавській (на 14,1\%), 吾 Житомирській (на 11,3\%) та Івано-Франківській (на 11,1\%) областях (табл. 5).

Для виведення підприємств переробної сфери АПК на інноваційний розвиток потрібно вживати заходи з інноваційної реструктуризації.

Змістовою стрижневою складовою інноваційної реструктуризації है переробної промисловості АПК мають стати інноваційні зміни технологічної та організаційної його структури, зокрема галузевої, при цьому має бути враховано: Іి

- технічне оновлення на передовій технологічній базі основних виробничих фондів провідних промислових підприємств регіону, до яких 
відносять бюджетоформуючі підприємства, а також підприємства, які є "точками економічного зростання" або мають перспективу ними стати;

Табличяя 4

Кількість промислових підприсмств, що впроваджували інновації (продукцію та/або технологічні процеси), за видами економічної діяльності у 2018 році, од.

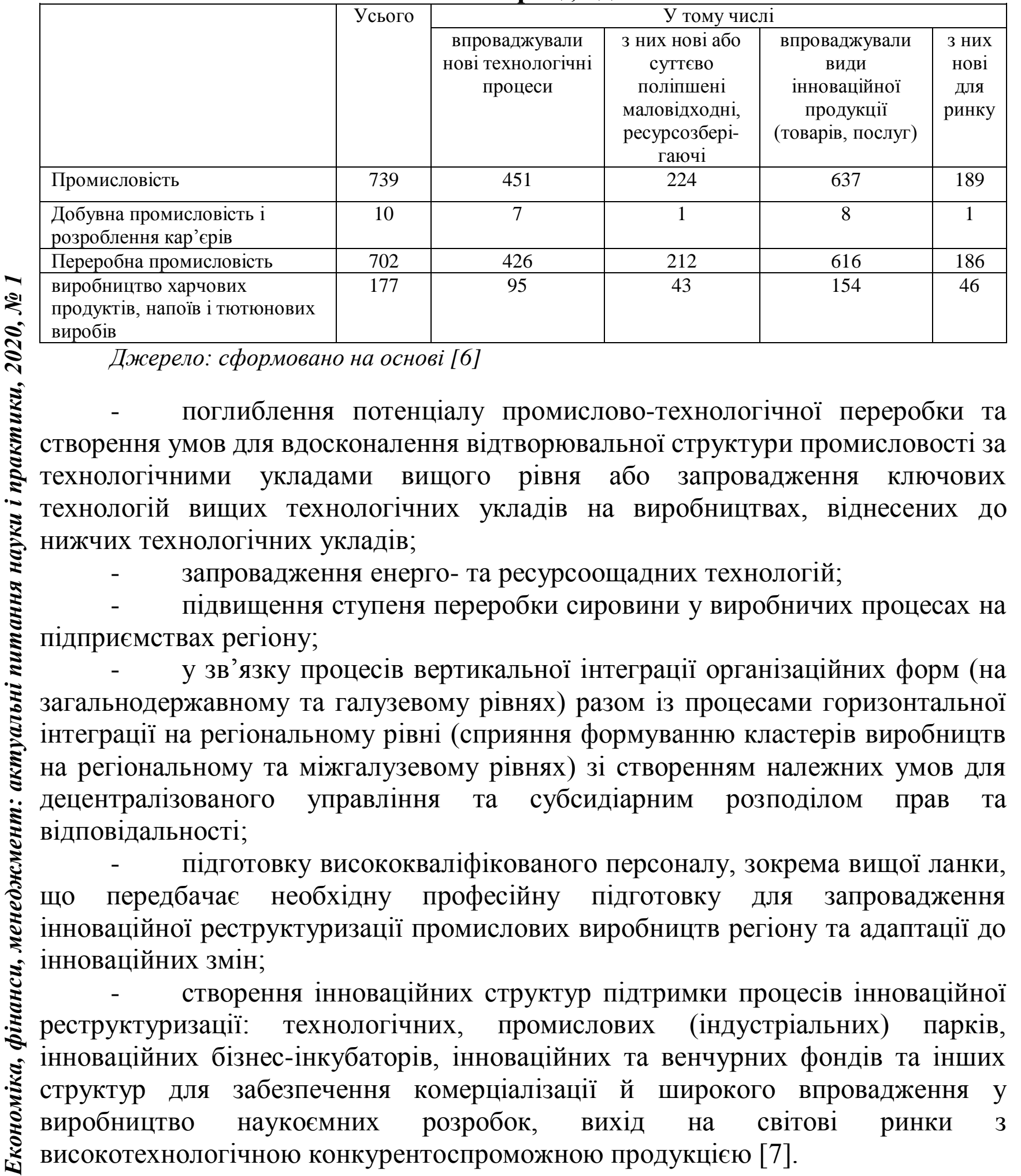


Використання газойлів (палива дизельного) за окремими регіонами у 2018 році

\begin{tabular}{|l|c|c|}
\hline \multicolumn{1}{|c|}{ Область } & Газойлі (паливо дизельне), & У \% до \\
& тис.т & $2016 \mathrm{p.}$ \\
\hline Україна & 5148,6 & 105,7 \\
\hline Вінницька & 221,7 & 105,2 \\
\hline Дніпропетровська & 494,3 & 104,7 \\
\hline Донецька & 197,6 & 105,7 \\
\hline Запорізька & 208,2 & 101,6 \\
\hline Київська & 289,7 & 104,3 \\
\hline Львівська & 316,9 & 102,0 \\
\hline Миколаївська & 194,4 & 104,6 \\
\hline Одеська & 338,3 & 106,5 \\
\hline Полтавська & 356,5 & 114,1 \\
\hline Харківська & 275,5 & 103,6 \\
\hline м.Київ & 329,4 & 117,9 \\
\hline
\end{tabular}

Джерело: сформовано на основі [10]

Шляхом обрахунків, представлених у таблиці 6, можна зробити висновок, що переробка зернових дасть можливість забезпечити потреби економіки у високооктановому паливі, залучити повною мірою потужності ДП «Укрспирт», збільшити зайнятість населення, а також отримати понад 37 млн тонн побічної продукції у вигляді барди, яка $є$ високонцентрованим кормом для тварин та ідеальним мінеральним добривом.

Таблиия 6

\section{Розрахунок економічної доцільності переробки зернових}

\begin{tabular}{|l|l|}
\hline \multicolumn{1}{|c|}{ Експорт зернових, тон } & \multicolumn{1}{|l|}{ Потенційний обсяг виробництва біоетанолу, л. } \\
\hline 42499000 & 15724630000 (11,64 млн тон) \\
\hline Експорт зернових, млрд дол. & $\begin{array}{l}\text { Потенційна вартість переробленої основної продукції } \\
\text { (середня ціна на біетанол 20,7грн/л) }\end{array}$ \\
\hline 6,8 млрд, дол. (при курсі 28,2грн/дол. 191,76млрд грн.) & 325,5 млр. грн. (11,5 млрд дол.) \\
\hline \multicolumn{1}{|l}{ Джерело: власні дослідження }
\end{tabular}

Створення переробних підприємств із переробки олії на біодизель, окрім збільшення валового продукту на більш ніж 2 млрд дол., дасть можливість забезпечити повну енергонезалежність сільського господарства (табл. 7).

Розвиток переробки олійних культур для енергетичних потреб економіки держави дасть можливість не лише забезпечити енергетичну незалежність насамперед самого сільського господарства, але матиме i такі позитивніз наслідки:

забезпечення замовленнями промисловості, адже потрібна досить значна кількість установок для переробки;

зростання рівня зайнятості населення в сільській місцевості: ్̃̃ (більшість установок будуть забезпечувати потреби в пальному насамперед $\mathrm{y}_{\text {: }}^{\text {s }}$ сільському господарстві);

забезпечення галузь тваринництва високонцентрованими кормами у вигляді макухи (побічна продукція при переробці олійних); 

біодизель;

розвиток спиртової галузі як виробника спирту для переробки олії на додаткове виробництво близько 600 тис. тонн гліцерину для потреб парфумерної промисловості.

Таблиия 7

Розрахунок економічної доцільності переробки олії на біодизель

\begin{tabular}{|c|c|}
\hline Експорт олії, тон & Потенційний обсяг виробництва біодизеля, т. \\
\hline 5988000 & 5988000 \\
\hline Експорт олії, млрд., дол. & $\begin{array}{c}\text { Потенційна вартість переробленої основної } \\
\text { продукції (середня ціна на біодизеля 31грн/л) }\end{array}$ \\
\hline 4,6 млрд, дол. (при курсі 28,2/дол. 130,1млр.грн.) & 185,6 млр грн. (6,6 млрд дол.) \\
\hline
\end{tabular}

Джерело: власні дослідження

Модель розвитку інновацій у переробній промисловості агропромислового комплексу має в себе включати такі складові:

заходи державного планування пріоритетних напрямків розвитку خे переробної промисловості АПК; правової бази, розвитку практики асигнувань та створення сприятливого інвестиційного клімату;

заходи державного регулювання через удосконалення нормативно-

- державне стимулювання через пільгове оподаткування, розробити систему страхування інновацій, у тому числі через страхові компанії;

- розвивати діяльність бізнес-інкубаторів, інноваційних центрів, технопарків та технополісів;

- розвиток інновацій на самих підприємствах через формування інноваційної політики, організації інноваційної діяльності, мотивації та здійснення заходів контролінгу (рис.1).

Особливо актуальним $\epsilon$ страхування фінансових ризиків, адже воно дозволяє підприємствам компенсувати збитки внаслідок пожежі, стихійних лих, аварій, банкрутства контрагента, банкрутства банку контрагента, тимчасової неплатоспроможності контрагента та навіть провалу проєкту з інноваційного розвитку (рис. 2).

Отже страхування фінансових ризиків може як дати передумови для уникнення фінансової реструктуризації, якщо дані ризики були застраховані завчасно, так і зменшити можливі фінансові втрати в разі невдалих інноваційних проєктів. А також при проведенні фінансової реструктуризації стати одним із інструментів спонукання кредитора до згоди на реструктуризацію заборгованості, що досить актуальне для переробних галузей АПК.

Інноваційна діяльність у переробних підприємствах АПК має бути підпорядкована досягненню своєї основної мети - максимально повному задоволенню запитів споживачів за кількістю та якістю запропонованої продукції, послуг при мінімальних затратах на їхню розробку, впровадження та реалізацію. 
ЕФМ

http://efm.vsau.org/

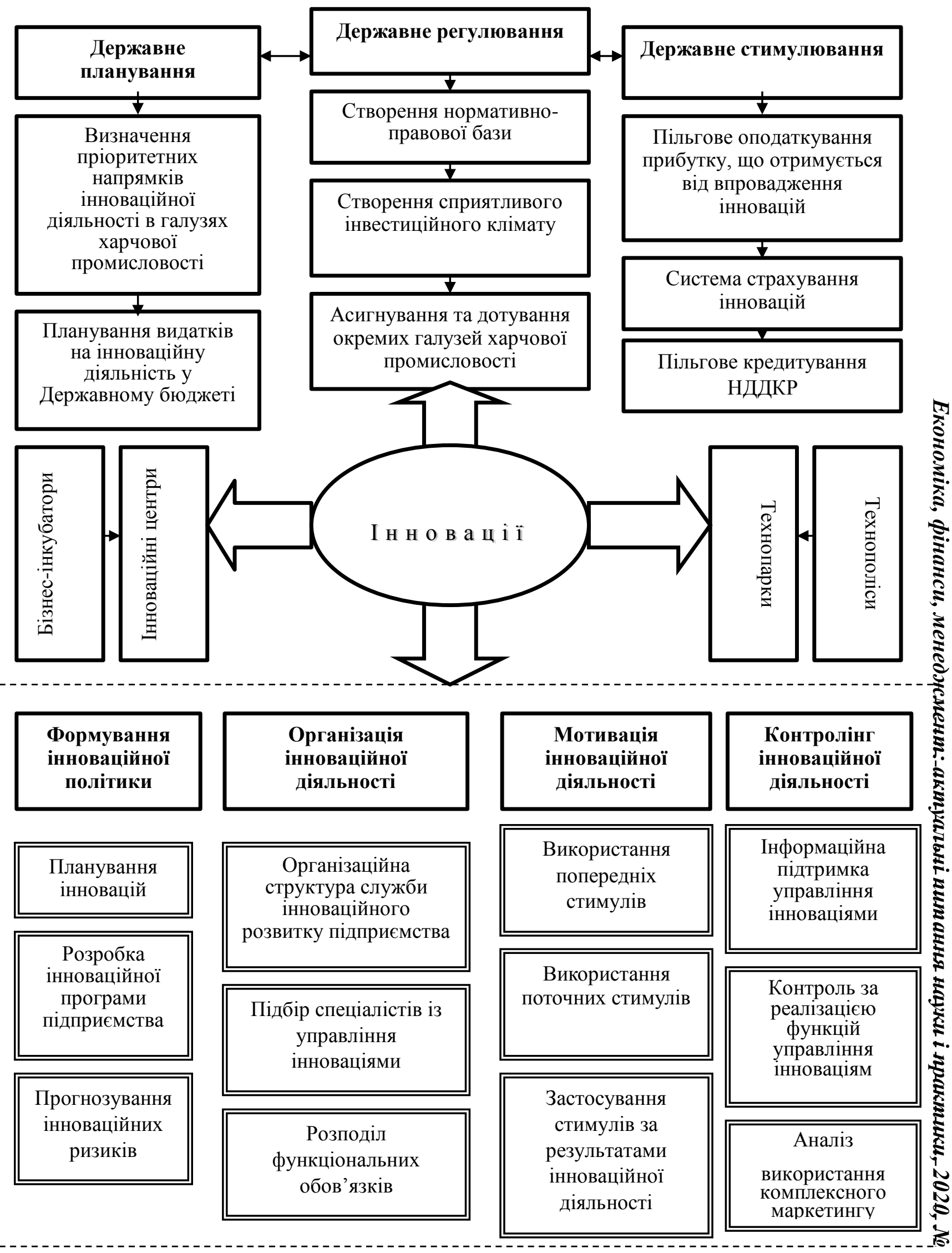

Рис. 1. Модель управління інноваціями на переробних підприємствах АПК

Джерело: власні дослідження 
Таким чином, інноваційна діяльність $є$ досить складною комплексною проблемою, потребує виділення інтерактивних варіантів і їхньої оптимізації. Зі зростанням на світовому i національному ринках конкуренції та розвитку науково-технічного прогресу впровадження інновацій у виробництво $\epsilon$ вирішальною умовою стійкого розвитку сучасних економічних систем. Імператив ринкової економіки - впровадження нововведень та перерозподілу ресурсів із менш ефективних сфер господарювання в найбільш ефективні під впливом конкуренції на ринку.

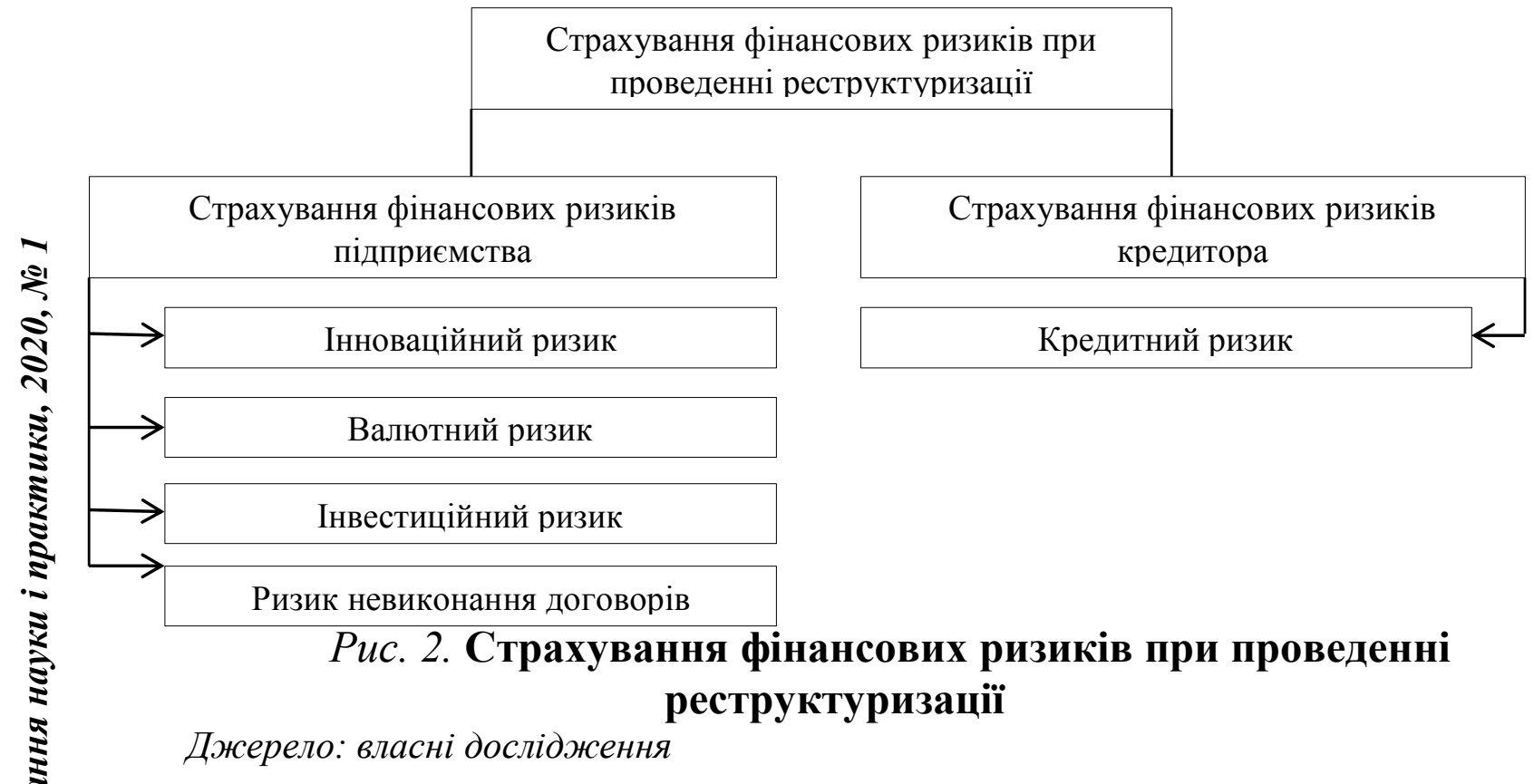

В умовах глобалізаційних процесів, що відбуваються в економіці країни для виходу на бажаний рівень конкурентоспроможності продукції потрібно дотримуватися такої інноваційної моделі:

1. провести реструктуризацію збиткових підприємств галузі;

2. залучити інвестиції у переробні галузі АПК;

3. диверсифікувати виробництва 3 орієнтацією на виробництво альтернативних джерел енергії;

4. д державна підтримка сільськогосподарських виробників;

5. розширення асортименту продукції та підвищення ï якості.

Для формування стійких конкурентних переваг підприємств цих галузей потрібно підходити 3 погляду системного підходу та проводити комплекс заходів, спрямований на:

1. реструктуризацію малоефективних підприємств галузі;

2. комплексну державну підтримку сільського господарства;

3. переорієнтацію із виробництва сировини на виробництво готової продукції;

4. диверсифікацію виробництва; 
5. залучення достатнього обсягу інвестицій для розвитку переробних галузей АПК.

Цей комплекс заходів дозволить оздоровити підприємства переробної промисловості та адаптувати їх до вимог глобалізованих ринків агропродовольства.

Висновки. Розвиток інновацій у переробних галузях АПК в умовах інтеграції національної економіки у світовий економічний простір $є$ одним із першочергових завдань для держави.

Розробка відповідного організаційно-економічного механізму зі створення інноваційного виду підприємницької діяльності, який дасть змогу подолати вище зазначені перешкоди для розвитку цього виду діяльності, має включати такі 3 етапи:

1. Поглиблених досліджень у сфері створення закритого циклу 3 переробки олійних культур, в тому числі на базі ННВК «Всеукраїнський sิ науково-навчальний консорціум»;

2. Економічного обгрунтування на основі проведених експериментальних досліджень доцільності створення переробних кооперативівіз виробництва біодизеля;

3. Створення проєктно-кошторисної документації 3 організації переробки олійної продукції та реструктуризації спиртових заводів на: інноваційній основі.

4. Розробки державної програми розвитку обслуговувальних кооперативів із передбаченням державного дотування переробної галузі АПК.

Організаційно-економічний механізм інноваційного розвитку підприємств переробної промисловості АПК із виробництва біодизелю має в себе включати заходи розробки дослідно-конструкторської документації прототипу закритого циклу з переробки олійних культур. Розробки універсального бізнес-плану 3 функціонування обслуговувальних кооперативів із надання послуг із переробки олійних культур для виробничих потреб сільськогосподарських формувань. Створення програм державної підтримки енергокооперативів. Розробки комплексу заходів з розвитку енергетичної кооперації в сільській місцевості.

\section{Список використаної літератури}

1. Савицький Е. Е. Інноваційні технології в аграрній сфері: сутність, класифікація та українські реалії. Економіка АПК. 2014. № 2. С. 110-115. URL: http://nbuv.gov.ua/UJRN/E_apk_2014_2_18. (дата звернення 19.03.2020).

2. Калетнік Г. М., Гончарук Т. В. Інноваційне забезпечення розвитку біопаливної галузі: світовий та вітчизняний досвід. Бізнес Інформ. 2013. № 9. С. 155-160. URL: http://nbuv.gov.ua/UJRN/binf_2013_9_26 (дата звернення : 19.03.2020).

3. Гончарук I. В. Підприємницька діяльність як інноваційна система розвитку виробництва біопалива. Інновачійна економіка. 2013. № 7. С. 155-159. 
4. Гонтарук Я.В. Перспективи розвитку академічного підприємництва в аграрних закладах вищої освіти України. Розвиток академічного підприємництва в закладах вищої освіти та наукових установах України: Круглий стіл м. Київ, 2019, відп. ред. Д.Ю. Чайка. К., 2019. С. 46-49.

5. Губіна В. В. Інновації як фактор конкурентоспроможності в харчовій промисловості. Ефективна економіка. 2013.2 № 7. URL: http://nbuv.gov.ua/UJRN/efek_2013_7_71. (дата звернення 19.03.2020).

6. Brenner Th. Science, Innovation and National Growth [electronic resource]. Annual Conference 2015 (Muenster): Economic Development Theory and Policy, Verein für Socialpolitik. http://EconPapers.repec.org/RePEc:zbw:vfsc15:112873. (дата звернення 19.03.2020).

7. J.R. Himenez. A non-parametric approach to innovation gaps and economic growth [electronic resource]. Journal of Economic and Financial Studies $(J E F S)$ 2015. Issue 5. P. 63-69.

URL: http://EconPapers.repec.org/RePEc:lrc:lareco:v:3:y:2015:i:5:p:63-69. звернення 19.03.2020).

8. Наукова та інноваційна діяльність Украӥни. Статистичний збірник. Державна служба статистики України. Київ. 2019 р. 107c.

9. Гусєв В. О. Імперативи i основні напрями інноваційної реструктуризації промислового комплексу України. Державне управління: теорія та практика. 2008. № 1. C. 29-40. URL: http://www.nbuv.gov.ua/ejournals/Dutp/2008-1/txts/GALUZEVE/06gvosvo.pdf. (дата звернення 19.03.2020).

10. Сайт Державної служби статистики України. [Електронний ресурс]. URL: www.ukrstat.gov.ua. (дата звернення: 19.03.2020).

\section{References}

1. Savytskyi E. E. (2014). Innovatsiini tekhnolohii v ahrarnii sferi: sutnist, klasyfikatsiia ta ukrainski realii. [Innovative technologies in agrarian sphere: nature, classification and Ukrainian realities]. Ekonomika APK. № 2. S. 110-115. URL: http://nbuv.gov.ua/UJRN/E_apk_2014_2_18. [in Ukranian]. (data zvernennia: 19.03.2020).

2. Kaletnik H. M., Honcharuk T. V. (2013). Innovatsiine zabezpechennia rozvytku biopalyvnoi haluzi: svitovyi ta vitchyznianyi dosvid. [Innovative support for the development of the biofuels industry: world and national experience ]. Biznes Inform. № 9. S. 155-160. URL://nbuv.gov.ua/UJRN/binf_2013_9_26. [in Ukranian]. (data zvernennia: 19.03.2020).

3. Honcharuk I. V. (2013). Pidpryiemnytska diialnist yak innovatsiina systema rozvytku vyrobnytstva biopalyva. [Entrepreneurship as an innovative system for the development of biofuel production. Innovative economy]. Innovatsiina ekonomika. № 7. S. 155-159. [in Ukranian].

4. Hontaruk Y.V. (2019). Perspektyvy rozvytku akademichnoho pidpryiemnytstva $\mathrm{v}$ aharnykh zakladakh vyshchoi osvity Ukrainy. [Prospects for the 
development of academic entrepreneurship in agar higher education institutions of Ukraine]. Rozvytok akademichnoho pidpryiemnytstva $v$ zakladakh vyshchoi osvity ta naukovykh ustanovakh Ukrainy: Kruhlyi stil (m. Kyiv, 16 travnia 2019), vidp. red. D.Iu. Chaika. K., s. 46-49. [in Ukranian].

5. Hubina V. V. Innovatsii yak faktor konkurentospromozhnosti v kharchovii promyslovosti. [Innovation as a factor of competitiveness in the food industry.]. Efektyvna ekonomika. 2013. № 7. URL: http://nbuv.gov.ua/UJRN/efek_2013_7_71. [in Ukranian]. (data zvernennia: 19.03.2020).

6. Brenner Th. Science, Innovation and National Growth [electronic resource]. Annual Conference 2015 (Muenster): Economic Development Theory and Policy, Verein für Socialpolitik. German Economic Association. URL: http://EconPapers.repec.org/RePEc:zbw:vfsc15:112873. [Aaccessed 07 Vart 2020].

7. J.R. Himenez. 2015. A non-parametric approach to innovation gaps and economic growth [electronic resource] Journal of Economic and Financial Studies

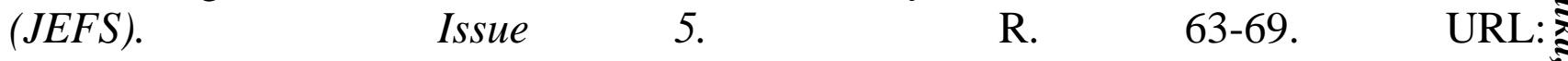
http://EconPapers.repec.org/RePEc:lrc:lareco:v:3:y:2015:i:5:p:63-69. [Aaccessed 07 Vart 2020].

8. Naukova ta innovatsiina diialnist Ukrainy. Statystychnyi zbirnyk. Derzhavna sluzhba statystyky Ukrainy. Vidpovidalnyi za vypusk M. S. Kuznietsova. Kyiv. 2019 r. 107s. [in Ukranian].

9. Husiev V. O. (2008). Imperatyvy i osnovni napriamy innovatsiinoi restrukturyzatsii promyslovoho kompleksu Ukrainy. [The imperatives and main directions of innovative restructuring of the industrial complex of Ukraine]. Derzhavne upravlinnia: teoriia ta praktyka. № 1. S. 29-40. URL: //www.nbuv.gov.ua/ejournals/Dutp/ 2008-1/txts/GALUZEVE/06gvosvo.pdf. (data zvernennia: 19.03.2020).

10. Sait Derzhavnoi sluzhby statystyky Ukrainy. [Elektronnyi resurs]. URL: www.ukrstat.gov.ua. (data zvernennia: 19.03.2020).

\section{Відомості про автора}

ГОНТАРУК Ярослав Вікторович - асистент кафедри аграрного менеджменту, Вінницький національний аграрний університет $(21008$, м. Вінниця, вул. Сонячна, 3, e-mail: e050122015@ gmail.com ).

HONTARUK Yaroslav - Lecturer of the Department of Agrarian Management, Vinnytsia National Agrarian University, (21008, Vinnytsia, 3 Solnyschaya st., 3 e-mail: e050122015@gmail.com).

ГОНТАРУК Ярослав Викторович - ассистент кафедры аграрного менеджмента, Винницкий национальный аграрный университет $(21008$, г. Винница, ул. Солнечная, 3, e-mail: e050122015@gmail.com). 